\title{
From Negative Feeling to Well Adjusted Person: Experience of Middle-Aged Women in Empty Nest Phase
}

\author{
Ni Km. Peby Darmayanthi ${ }^{{ }^{*}}$, Made Diah Lestari ${ }^{2}$ \\ ${ }^{1,2}$ Psychology Department, Faculty of Medicine Udayana University, Bali, Indonesia \\ *Email: febydarmayanthi@gmail.com
}

\begin{abstract}
The empty nest phase is a phenomenon occurs when the child begins to run their independent life. Empty nest syndrome refers to feelings of loss or grief experienced by parents, mostly mothers since most of her time spent by parenting. A good adjustment is highly recommended to the parents, especially mothers in order to cope the empty-nest syndrome in a positive way. The aim of this research was to find the stage of the adjustment process of middle-aged women in empty-nest phase. This research used qualitative method with phenomenological approach. The population of the study was women in midlife who entering empty nest phase. By purposive sampling method, the writers had three families as respondents in empty nest phase. The data were collected using interview and observation technique, with theoretical coding analysis technique. By this research, the writers found five stages of the adjustment process, they are: negative feeling, flashback memory, get used to the empty nest, universality \& adjustment to the empty nest.
\end{abstract}

Keywords: Adjustment, Empty-Nest, Empty-Nest Syndrome

\section{Background of the Study}

A family is a social group characterized by common residence, economic cooperation and reproduction (Murdock, 1965). Families grow and change over time in a similar and consistent way. Family and its members must perform a specific task both individuals or groups in the society at a certain time (Duvall \& Miller, 1985).

When parents entering the middle age period, child begins to leave their childhood homes and run their independent life known as the empty nest phase. (Hurlock, 1980).

In this phase, parents are left with the empty nest syndrome which refers to the feelings of depressions, sadness or grief after the children come of age and leave their childhood homes (Bararah, 2010).

This period usually occurs in 25 to 35 years marriage when couples are entering their middle age period (Levinson, 2004). According to Bararah (2010), empty nest syndrome affects the life and health of parents because it is assumed to cause stress and depression. The new adjustment process is likely to happen when the parents are 'losing' the children (Bassoff in Santrock, 2002).

Women are more likely affected by this syndrome than men (Bararah, 2010). This is because mothers usually have a strong relationship with the children and most of their time spent by parenting. Mitchell \& Lovegreen (2009) mentioned that women experience on losing motherhood role influence their vulnerability on empty-nest syndrome. Moreover, parental status gives tremendous impacts on psychological well-being of individual (Hansen, Slagsvold, \& Moum, 2009).

In Bali, most of the people follow patrilineal kinship known as Kapurusa. Kapurusa is a system where woman has to leave the family to stay in her husband's house and have a full responsibility (swadharma) on the new family (Atmaja, 2009).

In Bali, when a family has more than one child, one of them has to stay for the house responsibility, whereas others are leaving the house after marriage. However, there are also some families who prefer their children to stay in one house after marriage 
(Atmaja, 2009). So, that is why most Balinese families embraced the extended family structural. Otherwise, according to Swarsi (in Rospita, 2016), there are also some couples who choose to live separately from the family. This is known as the nuclear family.

Faturochman (2001) stated with the decreasing number of children in the family, nowadays Balinese are started to embrace the nuclear family more than extended family. The Nuclear family provides an opportunity for younger family members to have a better education (Ediastuti \& Faturochman in Faturochman, 2001) and when the children of this family decide to marry or continue their education, parent must be ready to release his child from the 'nest'. On the other hand, Balinese kinship system and custom are relative cohesive thus living together with adulthood children become implicit norm among families in Bali. Bali also one of the cultures in Indonesia which adopt traditional view that parents caregiving is adult's children responsibility.

When the child leaves home, parents will face new adjustments due to the absence of children, the decreasing of parental duties and the increasing spare time which is sometimes very disturbing. Losing the role of being a mother will be the beginning of the adjustment in empty nest phase. Adjustment is the ability to maintain the existence or to survive and gain prosperity both physically and spiritually (Kartono \& Andri, 2001).

Someone who has a good self-adjustment in empty nest phase will tend to make good preparation and planning to overcome it or at least reduce the concerns arise, so parents could be more realistic and objective with the situation (Hurlock, 1980).

In handling the empty nest phase, middle-aged woman certainly going through many kinds of adjustment process in a various way. Therefore, this study will explain deeply about the adaptation stage of middle age women in empty nest phase.

\section{Method}

Sample. The sample of this study are three middle age mothers in the age range of 40-60 years old who currently not living with her child for various reason; marriage, college, etc in Denpasar. The technique of sample selection was using the purposive sampling.
Research Design. This research used qualitative method and phenomenological approach.

Research Instrument. In conducting this paper, the writers used interview and observation technique. The interview was done by using some guidelines in order to find some aspects, such as respondent identity, respondent relationship with children, respondent opinion about the empty nest phase, the adjustment process of the empty nest phase, marital relationship, the meaning of family, social relation and personal desire. On the next interview, the guideline is determined according to the results of each respondent.

The participants were interviewed twice until three times based on inquiries and probing questions were needed during the interview and observation. Interviews with significant others were conducted as a data confirmation technique.

Procedure. The research was conducted between March until May 2017. Researcher used note-taking and field note to organized data. This research used theoretical coding technique in the process of data analysis which consists of three stages; open coding, axial coding, and selective coding (Strauss \& Corbin, 1990)

\section{Result}

Below are each category of empty nest syndrome that authors get from the interviews and observations.

The cause of empty nest syndrome are different living quarters, the children's condition, the difference of daily routines, loneliness, and losing the meaning of the family.

Some of the factors that support the adjustment of the empty nest phase are understood the reason of the children leave, support of the husband, intense communication with the child, good relationships with friends and also having new activities to distract the feeling of loneliness in empty nest syndrome. However, there are also some factors that inhibit the adjustment of the empty nest phase such as fluctuating emotional changes due to menopause, the respondent's close feeling to the child and the memories of the time spent with the children.

In adjusting the empty nest phase, mothers need to increase the intense communication with the child, spending time with friends and husband, having more religious life to balance the body and mind. Then, mothers who adjust the empty nest phase are 
most likely to accept all changes in life, realizing husband as a living companion, and sharing experience with friends.

By this research, the writers found five stages of adjustment process in empty nest phase:

\section{a. Negative Feeling}

This stage occurs the first 0 months after the child leaves home. The feelings experienced by the respondent at this stage are fear of losing the child, worried about the children condition, empty feeling and loneliness.

Things to do at this stage were consulting the experts, doing activities to reduce loneliness such as reading or watching television and visiting the relatives.

\section{b. Flashback Memory}

The next stage is the flashback memory. This stage occurs in $6^{\text {th }}$ month after the children leave home. At this stage, the appreciation of husband and wife relationship will increase. Sometimes, respondent will have the thought of her children, which is also influenced by fluctuating emotions due to menopause.

At this stage, the respondent usually doing some hobbies or activities with husband and also doing some intense communication with the children. The respondent who experienced empty nest syndrome due to children marriage will be able to adjust this phase in the $6^{\text {th }}$ month by getting along with the family.

To the respondents who are experienced empty nest phase due to children marital and still lived in the same town usually can achieve adjustment on the sixth months after the children offspring. The most important thing in this situation is to stay healthy and get along with the family.

\section{c. Get used to the empty nest.}

The third stage is get used to the empty nest. This stage occurs in the $12^{\text {th }}$ month after the child leaves. At this stage, respondents are started to control their feelings toward kids. Besides, the middle age women at this stage also realizing that the reason the children leave. At this stage, respondents are more likely to their feelings experienced by friends or relatives.

\section{d. Universality}

This stage occurs in the $18^{\text {th }}$ month after the children leave. At this stage, the respondents slowly understand the reason for the child leaving. Referring to get used to the empty nest, respondents are starting to raise their empathy to others by changing their way of thinking and having more religious life.

\section{e. Adjustment to the empty nest phase}

The last stage occurs on the $24^{\text {th }}$ month when the respondents are finally adjusted to this syndrome. At this stage, the respondents are fully accepting the changes in their life and moving on with their life.

\section{Discussion and Conclusion}

Discussion. Based on the data found in this study, the empty nest syndrome is caused by several reasons: different living quarters, the children condition, the difference of daily routines, productive husband and losing the meaning of a family. Regarding the previous researches, there are several factors which influence the degree of empty nest syndrome, namely the level of education, parents employment status, marital status of the parents, the age of children when leaving home, cultural background, demographic and relational process (Liang \& Wu, 2014; Piper \& Jackson, 2017; Dor \& Rojas, 2016; Mitchell \& Wister, 2015; Mitchell \& Lovegreen, 2009; Hogg, Curasi, \& Maclaran, 2004). The symptoms of empty nest syndrome experienced by respondents in accordance with the statement of Barber (1989) which is anxiety. According to Daradjat (1983), anxiety is a manifestation of emotional processes, which occur when the person is having frustration and conflict. This syndrome mostly affects the physiological anxiety, such as fever, indigestion, respiratory distress (Daradjat, 1983). Furthermore, Duan, et.al (2017) found that psychological distress during empty-nest phase is associated with progression of white matter lesions and cognitive impairment in elderly. Unlike Duan, et.al (2017), research that conducted by Chang, et.al (2016) found that there were no significant differences on general characteristic, lifestyles, serum parameter, ultrasonic cardiogram (UCG) parameters, depression, quality of life, and various comorbidities between empty nest who living alone, empty nest who loving as a couple, and non-empty nest.

Another thing experienced by the respondents is feeling of emptiness due to the changing of daily habits. Hurlock (1980) says the changing of daily habits by physical and cognitive factor occurs in middle age women. The adjustment can only be done when the individual performs intense communication with the child. As what is stated by Dharmawati (2016) that one of the efforts to prevent the empty nest syndrome is maintaining good 
relationships with children and grandchildren. Technology invention has provided devices which could help communication between parents and children (Hogg, Curasi, \& Macalaran, 2004).

The things done to adjust this syndrome is spending time with friends to reduce the feelings of loneliness experienced by respondents. This action is in accordance with research conducted by Wardani (2012) who stated the importance of having a positive relationships with others is a way to adapt the empty-nest phase. Positive relationships include resilience, fun, intimacy and love. Friends could be a support when facing the empty nest phase (Hogg, Curasi, \& Maclaran, 2004). Friendship activities that benefit the are getting together with friends, sharing experiences, finding solutions to the problems encountered, visiting friends, attending important events of friends, running hobby, and doing physical activity (Lestari, 2017). Tanic, Louw, \& Buijzen (2017) in their investigation on social networking site (SNS) found that SNS use increased in the period when the child was leaving the parental home and decreased gradually after two years and reached a level as it was six months before the children leaving the house.

Respondents said other things that helped her in the adjustment process is support of the husband. By having quality time together, respondents are able to express her feeling so they are not feeling lonely and sad. This is accordance with the research conducted by Rahmah (2006) where husband has an important role in wife's life. Nagy \& Theiss (2013) there were several changes in couple relationship in empty nest phase. The changes including increased couple time, increased communication, decreased structure, increased freedom, and increased privacy. Conflict style applied by couple also give impacts on couple adjustment during empty nest phase (King \& Theiss, 2016).

These actions are influenced by several inhibiting factors of adjustment process such as fluctuating emotional changes due to menopause and close feeling to the child. Hurlock (1980) says women experience personality changes during menopause such as depression, irritable and self-critical.

Besides the inhibiting factors, there are also some factors that help the middle age woman in facing the empty nest phase, such as the awareness of the child leaving. According to Hurlock (1980), individual with good adjustment has a realistic and objective learning process, past experience and are most likely to appreciate the situations and problems.

Next factor that helps the adjustment process is the emotional support by the husband to pass through the empty nest phase. According to Akmalah (2014) research, emotional support from husband is helping the individual to adapt easily. Another factor that helps the respondent in adjusting to the empty nest phase is the focus of respondent. Duvall \& Miller (1985) states working mothers are mostly getting more satisfaction by the recognization as someone competent on her job. Success depends on how well mothers allocate their time and energy she gives in her work and other responsibilities.

Based on the factors mentioned above, it can be seen that the actions done by the respondents in handling the empty nest phase are influenced by several factors; the factors that inhibit the process of adjustments such as the fluctuating emotions due to menopause and the respondents' close feeling to the child.

Some factors that support the process of selfadjustment; understanding the reason for the child leaving, emotional support from husband, intense communication with children, good relationships with friends, the environment and work.

This study has some weaknesses because some data are not detail listed where writers may be missed some non-verbal information that may be important for this study.

Besides, the writers also find some difficulties in finding the appropriate respondents because most Balinese are still embracing the extended family system.

Conclusion. Based on the results and discussions described in this study, it can be concluded that there are five stages of the adjustment process in empty nest phase, such as negative feeling, flashback memory, get used to the empty nest, universality and adjusted to the empty nest phase. In every stage, the respondents will face different experience in order to adjust the empty nest syndrome.

The feeling of loneliness and worries experienced by the respondents in this syndrome will turn into a feeling of acceptance of the children leave. Such changes may occur due to intense communication 
with children, having new activities with friends, relatives and husband also living more religious way of life.

The actions taken by respondents in adjustment process are divided into two: the factors that inhibit the personal process and the factors that help the personal process. Factors that inhibit the adjustment process are fluctuating emotion due to menopause and the memories of togetherness with the children There are some ways to deal with empty nest syndrome; understanding the reason for the child leaving, emotional support from husband, intense communication with children, good relationships with friends, the environment and work.

The study needs further investigation in order to collect social demographic and culture dimensions which related to adjustment process in empty-nest phase and investigate how the process implied among fathers as well as mothers.

\section{References}

Atmaja, J. (2009). Perkawinan pada gelahang di Bali. Denpasar: Udayana University Press.

Bararah, V. F. (2010). 'Sindrom sarang kosong', saat anak meninggalkan rumah. Jakarta, Jakarta: Diunduh

dari http://health.detik.com/read/2010/07/01/083551/1 390690/763/sindrom-sangkar-kosong-saat-anakmeninggalkan-rumah tanggal 26 Oktober 2016

Barber, C. E. (1989). Transition to the Empty Nest. Lexington: Lexington Books.

Chang, Y., Guo, X., Guo, L., Li, Z., Yang, H., Yu, S., Sun, G., \& Sun, Y. (2016). Comprehensive comparison between empty-nest and non-empty nest elderly: A cross-sectional study among rural populations in Northeast China. International Journal of Environmental Research and Public Health, 13, 1-14. Doi: 10.3390/ijerph13090857.

Daradjat, Z (1983). Kesehatan mental. Jakarta: Gunung Agung.

Darmayanthi, N.K.M. (2016). Gambaran sindrom sarang kosong pada seorang ibu di Bali. Studi Kasus (Naskah Tidak Dipublikasikan). Program Studi Psikologi Fakultas Kedokteran Universitas Udayana.

Dharmawati, M.A. (2016). Upaya-upaya mencegah sindrom sarang kosong pada lanjut usia perempuan di Banguntapan, Bantul. Skripsi (Naskah Dipublikasikan). Fakultas Ilmu Pendidikan Universitas Negeri Yogyakarta.

Dor, A., \& Rojas, D. (2016). "They're still so young": Kibbutz parents coping with their adolescent children's normative home leaving. International Journal of Social Science Studies, 4(1), 28-35.

Duan, D., Dong, X., Zhang, H., Zhao, X., Diao, Y., Cui, Y., Wang, J., Chai, Q., \& Liu, Z. (2017). Emptynest-related psychological distress is associated with progression of brain white matter lesions and cognitive impairment in the elderly. Scientific Reports, 7, 1-10. Doi: 10.1038/srep43816.

Duvall, E. M., \& Miller, B. C. (1985). Marriage and development, $6^{\text {th }}$ ed. USA: Hurper \& Row Publisher, Inc

Faturochman. (2001). Revitalisasi peran keluarga. Buletin Psikologi Tahun IX No 2. 39-41. Yogjakarta: Universitas Gadjah Mada

Hansen, T., Slagsvold, B., \& Moum, T. (2009). Childlessness and psychological well-being in midlife and old age: An examination of parental status effects across a range of outcomes. Social Indicators Research, 1-32.

Hogg, M.K., Curasi, C.F., \& Macalaran, P. (2004). The (re-) configuration of production and consumption in empty nest households/ families. Consumption, markets, and culture, 7(3), 239-259.

Hurlock, E.B. (1980). Psikologi perkembangan: suatu pendekatan sepanjang rentang kehidupan, Edisi 5. Jakarta: Erlangga.

King, M.E., \& Theiss, J.A (2016). The communicative and physiological manifestations of relational turbulence during the empty-nest phase of marital relationship. Communication Quarterly, 1-23. Doi: 10.1080/01463373.2015.1129353.

Liang, X., \& Wu, W. (2014). Exploratory analysis of health-related quality of life among the empty-nest elderly in rural China: An empirical study in three economically developed cities in Eastern China. Health Quality OF Life Outcomes, 12-59.

Levinson, W. (2004). Medical microbiology \& immunology, Examination \& Board. New York: McGraw-Hill.

Mitchell, B.A., \& Wister, A.V. (2015). Midlife challenge or welcome departure? Culture and family-related expectations of empty-nest transitions. The International Journal of Aging and Human Development, 81(4), 260-280.

Mitchell, B.A., \& Lovegreen, L.D. (2009). The emptynest syndrome in Midlife Families. A multimethod exploration of parental gender differences and cultural dynamics. Journal of Family Issues, 30(12), 1651-1670.

Murdock, G. P. (1965). Social structure. the free-press. New York: The Free-Press.

Nagy, M.E., \& Theiss, J.A. (2013). Applying the relationship turbulence model to the empty-nest transition: sources of relationship change, 
relational, uncertainty, and interference from partners. Journal of Family Communication, 13, 280-300. Doi: 10.1080/15267431.2013/823430.

Olson, D. H., \& Defrain, J. (2000). Marriage family: intimacy, diversity, and strengths 5th edition. New York: McGraw Hill.

Piper, A., \& Jackson, I. (2017). She's leaving home: A large sample investigation of the empty nest syndrome. Berlin: The German SSocio-Economic Panel Study.

Rahmah, N. (2006). Penyesuaian diri ibu menghadapi sindrom sarang kosong. Skripsi (Naskah Dipublikasikan). Fakultas Psikologi Universitas Airlangga.

Rospita, I.O. Lestari, M.D. (2016). Penyesuaian dan kepuasan perkawinan pada perempuan Bali yang tinggal di keluarga inti dan keluarga batih. Jurnal
Psikologi Udayana Vol 3 No 3. 491-498. Denpasar: Universitas Udayana

Santrock, J.W. (2002). Life span development: perkembangan masa hidup, Edisi 2. Jakarta: Erlangga.

Strauss, \& Corbin. (1990). Basic of qualitative research: grounded theory procedures and techniques. USA: Sage Publication

Tanic, M., Louw, M.V., \& Buijzen, M. (2017). From empty-nest to social networking site: what happens in cyberspace when children are launched from the parental home?. Computer in Human Behavior, 68, 56-63.

Wardani, R. (2012). Kesejahteraan psikologis dan dukungan pasangan pada ibu "empty nester" di kota Bandung. Jurnal Vol 3 No 1 Th 2012. Bandung: Universitas Padjajaran. 